DOI: $\underline{\text { http://dx.doi.org/10.21123/bsj.2020.17.3.0780 }}$

\title{
Oxidative Coupling Reaction for Micro Trace Analysis of Mebendazol Residual with p-bromoaniline in Presence of $\mathbf{n}$ - bromosuccinimide
}

\author{
Takleef Dheyab Sallal ${ }^{1}$ \\ Sumayha Muhammad Abass ${ }^{2 *}$
}

\author{
${ }^{1}$ Ministry of Education, Baghdad, Iraq \\ ${ }^{2}$ Department of Chemistry, College of Education for Pure Science Ibn Al-Haitham, University of Baghdad, Baghdad, \\ Iraq. \\ *Corresponding author: *sumayha.mu@ gmail.com, sallaltakleef535@gmail.com \\ *ORCID ID: * https://orcid.org/0000-0002-0527-9982, https://orcid.org/0000-0002-7235-8023
}

Received 4/8/2019, Accepted 30/12/2019, Published 1/9/2020

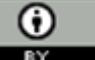

This work is licensed under a Creative Commons Attribution 4.0 International License.

\begin{abstract}
:
Rapid, reproducible and accurate method has been developed for the assay for of mebendazol (MBZ) residual assay. The method is based on alkaline hydrolysis of MBZ with sodium hydroxide then oxidation with N-bromosuccinimide (NBS) followed by coupling with 4-Bromoaniline (4-BA) to yield a highly colored product absorbed at maximum $434 \mathrm{~nm}$. Regression analysis of linearity range was found (0.6-2.8) $\mu \mathrm{g} . \mathrm{ml}^{-1}$. The optimum conditions that affect the oxidation were studied. The developed method was found to be precise with mean value of relative standard deviation (1.153-1.303) and accurate with relative error (0.5940-1.7821) .The calculated molar absorptivity and sandal sensitivity values of $\left(29825 \mathrm{~L}^{\mathrm{mol}}{ }^{-1} . \mathrm{cm}^{-1}\right)$, $0.0099 \mu \mathrm{g} . \mathrm{cm}^{-2}$ respectively. The limit of detection and limit of quantitation were of $0.04696,0.156548$ $\mu \mathrm{g} . \mathrm{ml}^{-1}$ respectively .The suggested method showed good recovery with a mean value of $100.77 \%$ for analysis of dosage forms.
\end{abstract}

Key words: Mebendazol, N- bromosuccinimide, Oxidation coupling, Spectrophotometry.

\section{Introduction:}

Mebendazol (MBZ) methyl 5benzoylbenzimLdazole-2-carbamate is one of the anthelmintic drugs(Fig.1). The principle mode of action for Mebendazole is by its inhibitory effect on tubulin polymerization which results in the loss of cytoplasmic microtules.It is used to treat hookworm, pinworm, round worm and mixed of infections. MBZ is highly used to treat gastrointestinal helming in both humans and animals (1). Mebendazole causes degenerative changes in intestinal blood cells and worm intestinal cells by binding to the collagen-sensitive topline site, thus inhibiting polymerization or aggregation in microtubules. The loss of microtubules, cytoplasm, impairs the absorption of glucose in the larval and adult stages of sensitive parasites and depletes the glycogen stock. It is available in tablet and suspension form. Depending on the type of worm to be treated, the dosage varies in adults and children (2).

Various analytical method is found for the assay of MBZ in different formulation dosage including UV-visible spectrometry (3-7), highperformance liquid chromatography (8-11), selective membrane sensor (12-14) and potentiometric analysis (14). The present work stand on oxidation of hydrolyzed MBZ in the presence of NBS then coupling with 4-BA to get a paled orang complex absorbed at $434 \mathrm{~nm}$ at $\mathrm{pH} 9$.<smiles>COC(=O)Nc1nc2ccc(C(=O)c3ccccc3)cc2[nH]1</smiles>

Figure 1. Chemical structure of mebendazol

\section{Materials and Methods: \\ Apparatus \\ - Shimadzu daual beam UV-Visible 1800 spectrophotometer (Japan)with matched 1-cm quartz cell \\ - pH meter type BP3001, Trans .Singapore \\ - Electronic balance type Sartorius, BL210 S, Germany.}




\section{Reagents}

All chemicals used are of highest purity available. MBZ pharmaceutical -grade was gifted from" State Company for Drug Industries and Medical Appliances Samara-Iraq (SDI)"

Stock Solution of Mebendazol (100 $\left.\mu \mathrm{g} . \mathrm{mL}^{-1}\right)$

$0.05 \mathrm{~g}$ of MBZ was dissolved with $10 \mathrm{~mL} 1 \mathrm{M}$ $\mathrm{NaOH}$ and the volume was adjusted to $500 \mathrm{~mL}$ to the mark with distilled water in $500 \mathrm{~mL}$ volumetric flask.

\section{4-Bromo Aniline $\left(5.8 \times 10^{-3} \mathrm{M}\right)$}

Reagent solution was prepared by dissolving 0.1 $\mathrm{g}$ from 4-BA in $10 \mathrm{ml}$ of methanol then completed the volume to the mark with distilled water in 100 $\mathrm{ml}$ volumetric flask.

N-Bromosuccinimide Solution $\left(1.1 \times 10^{-2} \mathrm{M}\right)$

$0.1 \mathrm{~g}$ from NBS was dissolved with distilled water then complete the volume to the $50 \mathrm{~mL}$ in a volumetric flask..

\section{Sodium Hydroxide Solution (1M)}

$4 \mathrm{~g}$ was weighted from $\mathrm{NaOH}$ to prepare $1 \mathrm{M}$ in 100 $\mathrm{ml}$ volumetric flask.

MBZ Syrup Formulation (100 $\left.\mu \mathrm{g} . \mathrm{mL}^{-1}\right)$

This solution was prepared by taking $0.5 \mathrm{ml}$ from each: Veromx (20 mg. $\mathrm{ml}^{-1}$ Belgium) and، mebandazol S-awa (20 mg.ml ${ }^{-1}$ Iraq) dissolved with $10 \mathrm{ml}$ of $1 \mathrm{M} \mathrm{NaOH}$ and complete the volume in $100 \mathrm{ml}$ volumetric flask.

\section{Recommended Procedure:}

In $5 \mathrm{ml}$ volumetric flask different aliquots (0.6-2.8) $\mu \mathrm{g} . \mathrm{ml}^{-1}$ from MBZ were added then $0.2 \mathrm{ml}$ from $5.8 \times 10^{-3} \mathrm{M}$ 4-NBA followed by $0.3 \mathrm{ml}$ from $1.1 \times 0^{-2}$ $\mathrm{M}$ NBS was added and the solutions were left for about 5 min in $15{ }^{\circ} \mathrm{c}$ then dilute it to the mark with methanol and recorded the absorbance of the colored complex at $434 \mathrm{~nm}$ against blank solution.

Procedures for Pharmaceutical Preparations (Suspensions):

To apply the suggested spectral method to pharmaceutical preparations, equivalent volumes of $(1,1.6,2) \mu \mathrm{g} . \mathrm{ml}^{-1}$ of $\mathrm{MBZ}$ commercial were transferred to $5 \mathrm{ml}$ volumetric flasks and supplemented by applying optimal conditions.

\section{Results and Discussion: \\ Spectral Characteristics}

The procedure contain basic hydrolysis of MBZ followed by the addition of 4-BA and the oxidation reagent to form orange color derivatives having $\lambda \max$ at $434 \mathrm{~nm}$. The other reagent blank have practically zero absorbance at this wavelength as shown in Fig. 2. The formation of a color complex with the reagents was shown in Scheme 1.

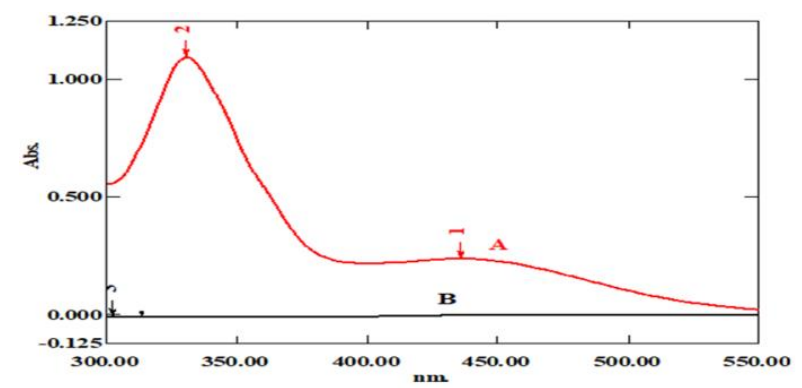

Figure 2. Absorption spectra of 2 ug $\backslash \mathrm{mLof}$ MBZ colored complex with p- bromo aniline

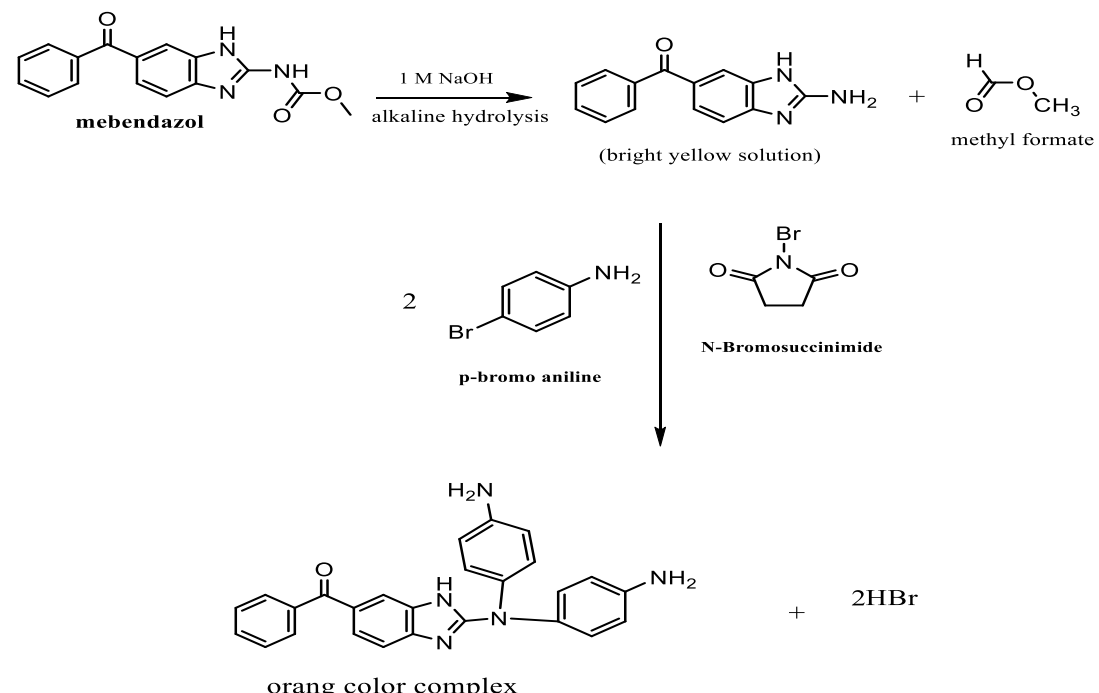

Scheme 1. Suggested oxidation coupling pathway of MBZ

\section{Optimization}

Alkaline hydrolysis of BNZ yields primary amino group with a bright yellow color solution.
The oxidation and coupling reaction was studied at different $\mathrm{pH}$ media, $\mathrm{pH} 9$ was suitable for best absorption values at $434 \mathrm{~nm}$ (Fig.3).For complete 
development procedure it was found that best volume of 4-BA is $0.2 \mathrm{~mL}$ from $\left(5.8 \times 10^{-3}\right.$ M)(Fig.4) , the optimum time to complete oxidation is $5 \mathrm{~min}$ (Fig.5), with $0.3 \mathrm{ml}$ of $\left(1.1 \times 10^{-2}\right.$ $\mathrm{M}$ )NBS (Fig. 6 ) at $15^{\circ} \mathrm{C}$. To study the effect of the order of addition for reagents to obtain the best results, it was clear from the study that the order of mentioned method gave the best results (drug, reagent and oxidative reagent) (Fig.7), otherwise the solution was colorless. The study investigated different solvents to dilute the solutions, methanol appear a suitable for color development

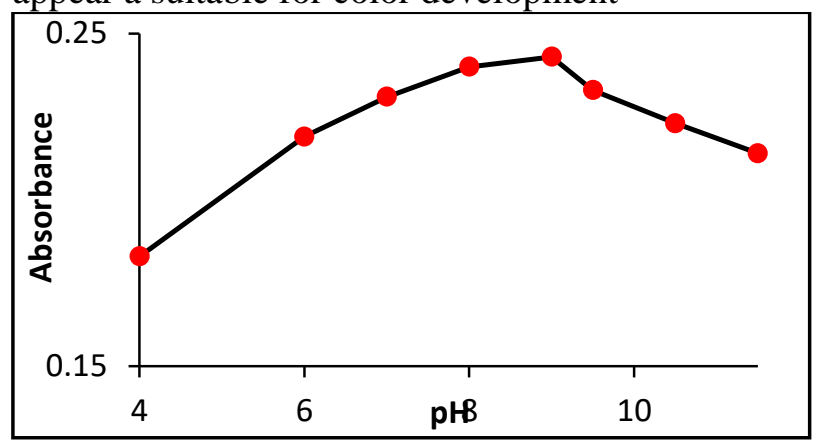

Figure 3. Effect of $\mathrm{pH}$ on determination of $2 \mu \mathrm{g} \backslash \mathrm{mL}$ of $\mathrm{MBZ}$

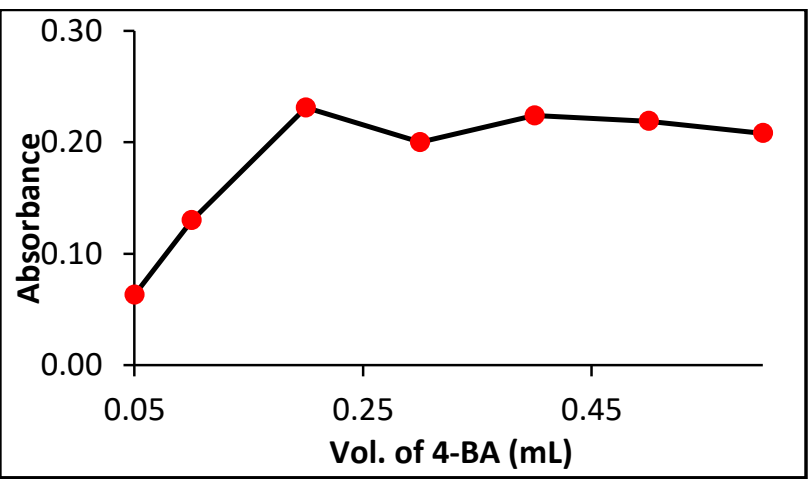

Figure 4. Effect of 4- $\mathrm{BA}$ volume of $\left(5.8 \times 10^{-3} \mathrm{M}\right)$ on determination of $2 \mu \mathrm{g} \backslash \mathrm{mL}$ of $\mathrm{MBZ}$

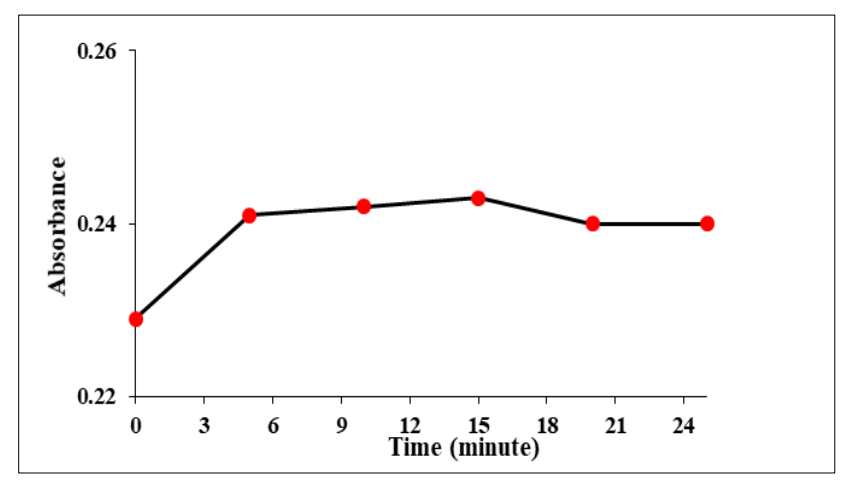

Figure 5. Effect the time on determination of $2 \mu \mathrm{g} \backslash \mathrm{mL}$ of $\mathrm{MBZ}$

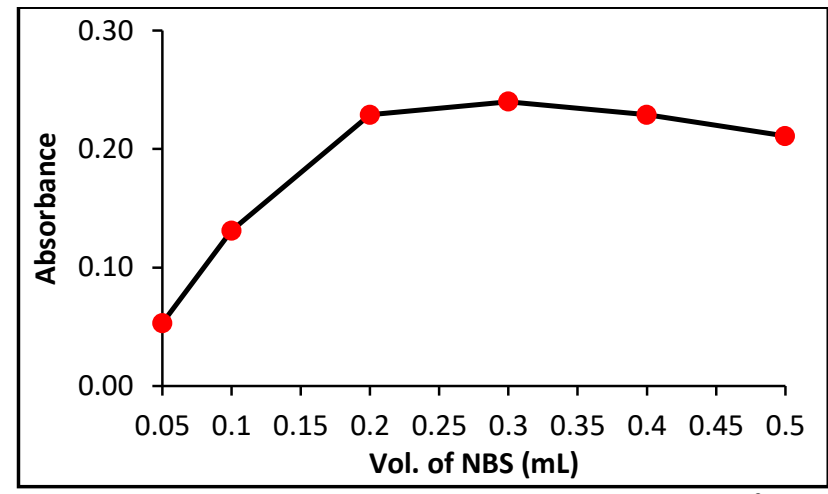

Figure 6. Effect of NBS volume of $\left(1.1 \times 10^{-2} \mathrm{M}\right)$ on determination of $2 \mu \mathrm{g} \backslash \mathrm{mL} \mathrm{NBZ}$

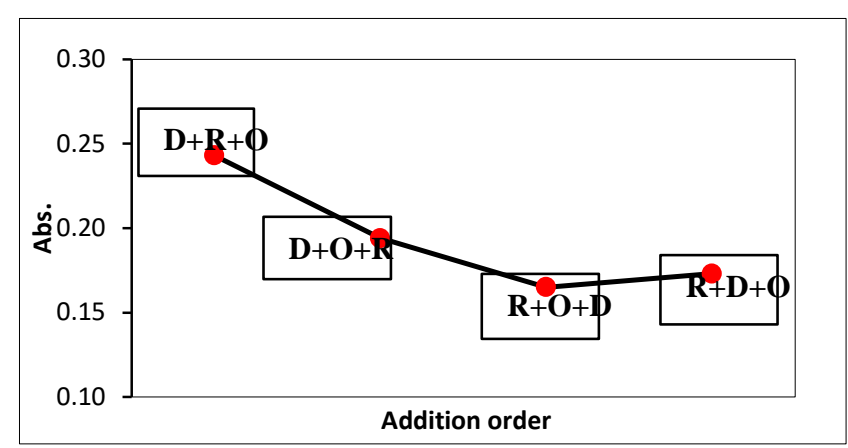

Figure 7. Effect of addition order on determination of $2 \mathrm{ppm}$ of $\mathrm{MBZ}$ ( (D: Drug, $R$ : Reagent, O: Oxidative agent)

\section{Calibration and Analytical Data}

Applying the best condition on the work to investigate calibration and optical characteristics for different concentration (0.6-2.8) $\mu \mathrm{g} \cdot \mathrm{ml}^{-1}$ (A) versus absorbance was done and the residual plot showed random distribution of error and no presence of systematic error (B), (C) represent the comparison between real and predicated absorbance value as showed in Fig. 8, the statistical data can be seen in Table 1 . 

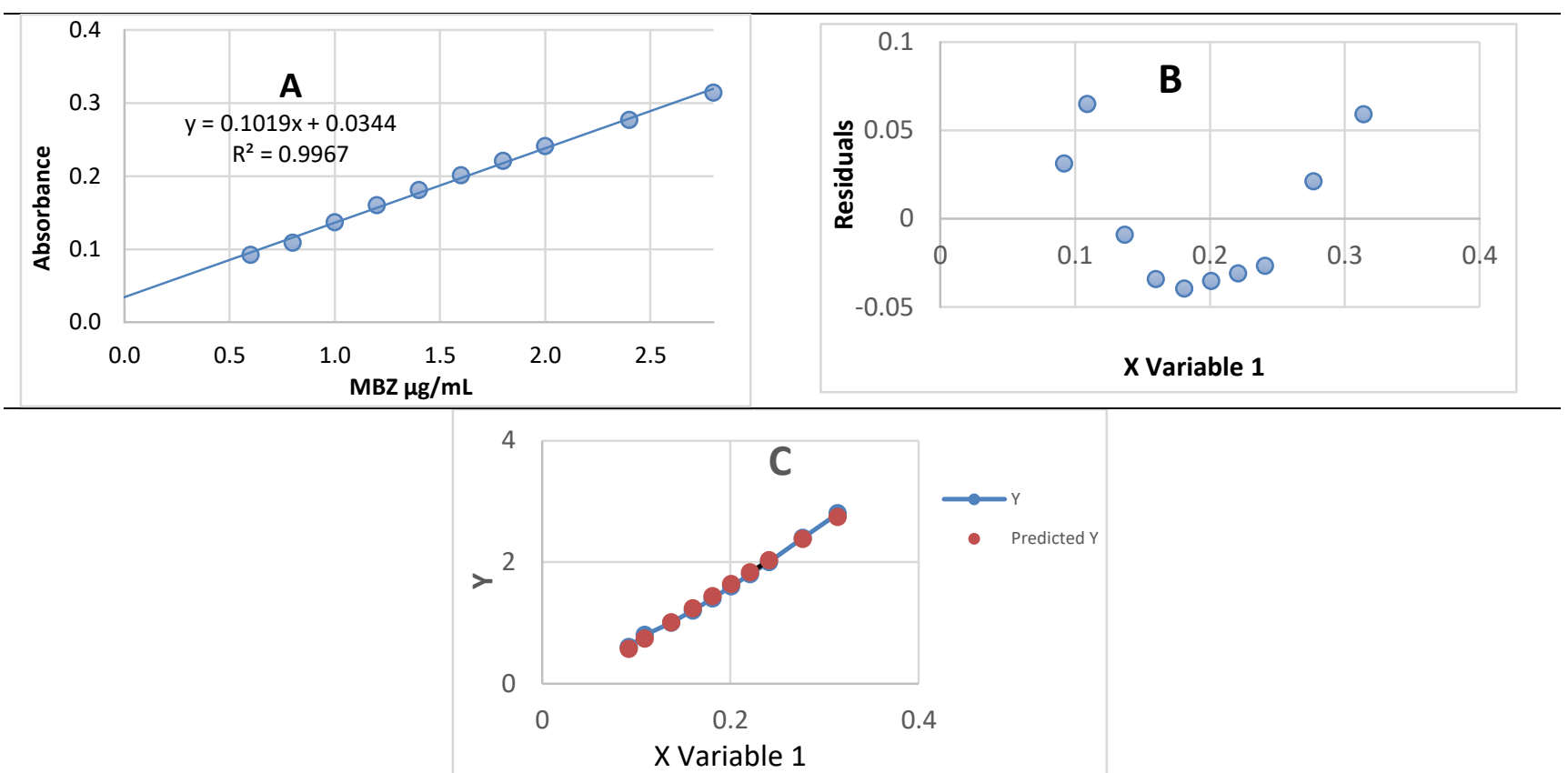

Figure 8. (A) Calibration curve,(B) plot of residual,(C) predicated y verses concentration .

Table 1. Analytical parameter of calibration curve

\begin{tabular}{|c|c|}
\hline Parameter & Value \\
\hline$\lambda_{\max }(\mathrm{nm})$ & 434 \\
\hline Color & Pale orange \\
\hline Dynamic $\operatorname{rang}\left(\mu \mathrm{g} \cdot \mathrm{mL}^{-1}\right)$ & $0.6-2.8$ \\
\hline Molar absorptivity $\left(\mathrm{L} \cdot \mathrm{mol}^{-1} . \mathrm{cm}^{-1}\right)$ & 29825.3 \\
\hline Regression equation & $\mathrm{A}=0.1019 \mathrm{X}+0.0344$ \\
\hline Sandell's Sensitivity $\left(\mu \mathrm{g} . \mathrm{cm}^{-2}\right)$ & 0.0099 \\
\hline Correlation of Linearity $\left(\mathrm{R}^{2}\right)$ & 0.9967 \\
\hline Correlation coefficient (r) & 0.9983 \\
\hline $\operatorname{LOD}\left(\mu \mathrm{g} . \mathrm{mL}^{-1}\right)$ & 0.0469 \\
\hline LOQ $\left(\mu \mathrm{g} \cdot \mathrm{mL}^{-1}\right)$ & 0.1565 \\
\hline
\end{tabular}

\section{The Nature of the Colored Product}

The stoichiometry of drug with the reagent was studied by Job's method. The method required to prepare same concentration $\left(1.700 \times 10^{-3} \mathrm{M}\right)$ for each standard MBZ and 4-BA reagent solution. In Job's method, a series of volumetric flasks $(5 \mathrm{ml})$, different volumes of the drug solution ranging from (1-9) $\mathrm{mL}$ and (9-1) $\mathrm{mL}$ of reagent solution were mixed. A $0.3 \mathrm{ml}$ of $(\mathrm{NBS})\left(1 \times 10^{-2} \mathrm{M}\right)$ were added and volumes are completed to the mark with methanol. The absorbance was measured at $434 \mathrm{~nm}$ against the blank. The results in Fig. 9 shows that the ratio is $1: 2$.

Precision and Accuracy of the Suggested Method

The accuracy and precision value of the MBZ were evaluated by performing five replicate to three concentrations within the calibration curve to measure both relative error and standard deviation for both accuracy and precision respectively the result listed in Table 2 .

Table 2. Accuracy and precision for the suggested method

\begin{tabular}{|c|c|c|c|}
\hline $\begin{array}{l}\text { Taken Conc. } \\
\text { Mg.mL }^{-1}\end{array}$ & $\begin{array}{c}* \text { Found Conc. } \\
\mu \mathrm{g} . \mathrm{mL}^{-1}\end{array}$ & RSD\% & RE\% \\
\hline 1 & 0.994059 & 0.848345 & -0.59406 \\
\hline $\begin{array}{c}1.6 \\
2\end{array}$ & $\begin{array}{l}1.625743 \\
2.035644\end{array}$ & $\begin{array}{l}0.970504 \\
0.632961\end{array}$ & $\begin{array}{l}1.608911 \\
1.782178\end{array}$ \\
\hline
\end{tabular}

\section{Interference.}

Tables 3shows the effect of some interferences substances when added to the drug solution and its effect is measured by the absorption value of the drug solutions have $2 \mu \mathrm{g} / \mathrm{mL}$ of MBZ and different quantity of different species in a final volume of 5 $\mathrm{ml}$.

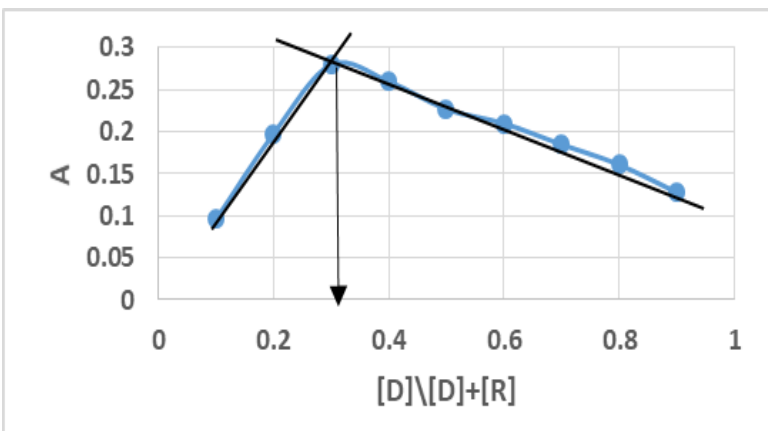

Figure 9. Job's plot for MBZ--NBA complex 
Table 3. The effect of excipients on determination of MBZ

\begin{tabular}{|c|c|c|c|}
\hline Interferences & Vol.(mL) & Found conc. (ppm) & Rec. $\%$ \\
\hline \multirow{2}{*}{ Vanillin } & 0.5 & 1.98 & 99.01 \\
\cline { 2 - 4 } & 1.0 & 2.00 & 100.50 \\
\hline \multirow{3}{*}{ Starch } & 0.5 & 2.02 & 101.49 \\
\cline { 2 - 4 } & 1.0 & 2.08 & 104.46 \\
\hline \multirow{2}{*}{ Gum Acxcia } & 0.5 & 1.93 & 96.53 \\
\cline { 2 - 4 } & 1.0 & 2.00 & 100.00 \\
\hline \multirow{2}{*}{ Na Stearate } & 0.5 & 1.90 & 95.05 \\
\cline { 2 - 4 } Glucose & 1.0 & 2.03 & 101.98 \\
\cline { 2 - 4 } & 0.5 & 1.92 & 96.04 \\
\hline \multirow{3}{*}{ Maltose } & 1.0 & 2.06 & 103.47 \\
\cline { 2 - 4 } & 0.5 & 1.91 & 95.54 \\
\hline \multirow{2}{*}{ Lactose } & 1.0 & 2.04 & 102.48 \\
\cline { 2 - 4 } & 0.5 & 1.89 & 94.55 \\
\hline \multirow{2}{*}{ Sucrose } & 1.0 & 2.06 & 103.47 \\
\cline { 2 - 4 } Cellulose & 0.5 & 1.95 & 97.52 \\
\cline { 2 - 4 } & 1.0 & 2.05 & 102.97 \\
\hline \multirow{2}{*}{. } & 1.0 & 1.91 & 95.54 \\
\hline
\end{tabular}

It is noted from this study that there is a large overlap shown by the citrate group (magnesium citrate, sodium citrate) and stearic acid in determination of MBZ because of the incompatibility between the active substance of the drug and this group, it causes increasing the dissolution of the drug, so it is preferable not to add it to the drug as a lubricating agents (added to improve manufacturability of the drug products) therefore it was neglected. Also it shows in table3 an overlap of the substance of the starch and all sugars in its high concentrations, this has been confirmed by previous studies. (15)

\section{Analytical Application of Dosage Forms of MBZ}

The suggested method was examined to quantitative analysis of MBZ, using the selected experimental conditions. In this method, different concentration $(1,1.6,2) \mu \mathrm{g} \cdot \mathrm{ml}^{-1}$ of a dosage formulation solution $\left(20 \mathrm{mg} \cdot \mathrm{ml}^{-1}\right.$ ) were spiked to $5 \mathrm{ml}$ volumetric flasks and were treated similar to working range. Five times replicate was done to measure absorbance at $434 \mathrm{~nm}$. RSD and Recovery were estimated and the results are shown in Table (4). Estimation of $1 \mathrm{ppm}$ of MBZ in dosage forms was applied with standard addition as it appear in Fig. 10 and 11 with recovery of $90 \%$.

Table 4. Determination of MBZ in pharmaceutical formulation

\begin{tabular}{|c|c|c|c|c|c|c|}
\hline Sample & $\begin{array}{c}\text { Amount } \\
\text { of drug } \\
\text { (mg) }\end{array}$ & $\begin{array}{c}\text { Taken } \\
\text { Conc. } \\
\left(\mu \mathrm{g} . \mathrm{mL}^{-1}\right)\end{array}$ & $\begin{array}{c}\text { Found } \\
\text { Con. } \\
\left(\mu g^{-1} L^{-1}\right)\end{array}$ & Recovery\% & SD & RSD\% \\
\hline Mebendazol-S-awa (MBZ & & 1 & 1.003 & 100.396 & 0.016 & 1.67 \\
\hline $20 \mathrm{mg} / \mathrm{mL})$ & 20 & 1.6 & 1.601 & 100.123 & 0.018 & 1.11 \\
\hline$t^{* *}=2.06$ & & 2 & 2.021 & 101.089 & 0.013 & 0.68 \\
\hline Veromx & & 1 & 1.011 & 101.188 & 0.022 & 2.27 \\
\hline$(\mathrm{MBZ} 20 \mathrm{mg} / \mathrm{mL})$ & 20 & 1.6 & 1.621 & 101.361 & 0.016 & 1.01 \\
\hline $\mathrm{t}=2.74$ & & 2 & 2.009 & 100.495 & 0.012 & 0.63 \\
\hline
\end{tabular}

*Average of five measurements.

** $t$ experimental(t tabulated $2.78 n=4)$, reference method $^{7}$

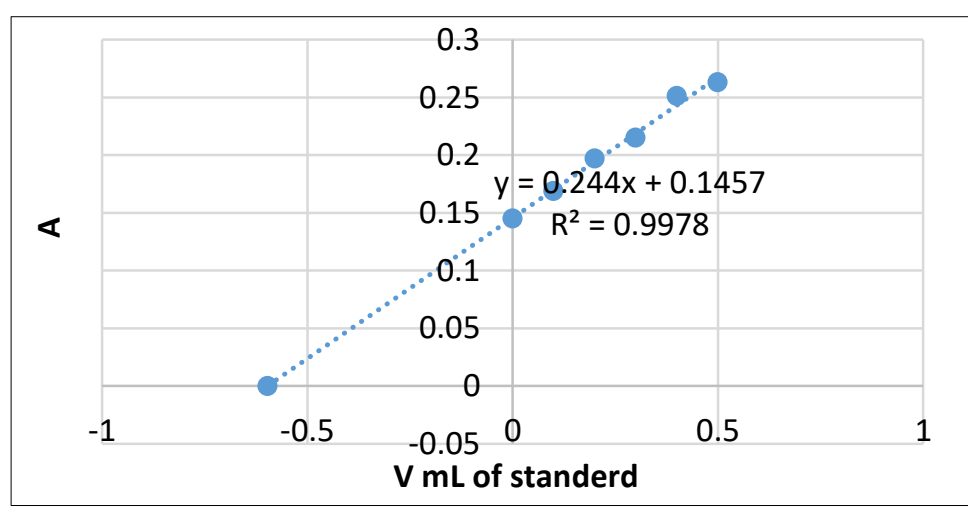

Figure 10. Standard addition application on determination of $1 \mu \mathrm{g} \backslash \mathrm{mL}$ of Mebendazole- S-awa (MBZ $20 \mathrm{mg} / \mathrm{mL}$ ) 


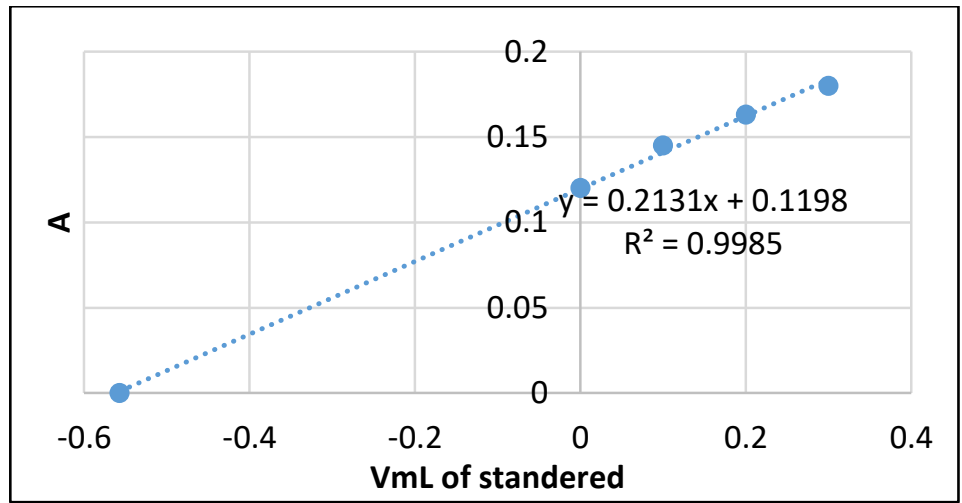

Figure 11. Standard addition application on determination of $1 \mu \mathrm{g} \backslash \mathrm{mL}$ of Mebendazole- Vermox (MBZ 20mg/mL)

\section{Conclusions:}

This study was done to estimate MBZ in pure and dosage forms. This method is considered simple, sensitive, selective and rapid. The process deals with alkaline hydrolysis of MBZ drug then oxidative coupling reaction takes place with a 4NBA in presence of NBS. The proposed method showed that it is more appropriate for estimating the low concentration of MBZ, while in high concentrations, less sensitivity it obtained because the interaction between the reagent and oxidized agent. The method is applied successfully in pharmaceuticals dosage and good recovery with high compatibility and accuracy values.

\section{Authors' declaration:}

- Conflicts of Interest: None.

- We hereby confirm that all the Figures and Tables in the manuscript are mine ours. Besides, the Figures and images, which are not mine ours, have been given the permission for republication attached with the manuscript.

- Ethical Clearance: The project was approved by the local ethical committee in University of Baghdad.

\section{References:}

1. Tian F, Yang J, Huang W, Zhou S, Yao G. Resonance Rayleigh scattering, frequency doubling scattering and absorption spectrum of the interaction for mebendazole with 12-tungstophosphoric acid and its analytical applications. A Mol Biomol Spectros. 2013 Dec 1; 116:57-64.

2. Swamy N, Basavaiah K. Selective and sensitive assay of mebendazole in pharmaceuticals using bromocresol green by spectrophotometry. TJPS. 2013 Oct $1 ; 37(4)$.

3. Swamy N, Prashanth KN, Basavaiah K. Spectrophotometric assay of mebendazole in dosage forms using sodium hypochlorite. J. Appl. Spectrosc. 2014 Jul 1; 81(3):525-33.

4. Santos AL, Takeuchi RM, Stradiotto NR. Electrochemical, spectrophotometric and liquid- chromatographic approaches for analysis of tropical disease drugs. Curr Pharm Anal. 2009 Feb 1; 5(1):6988.

5. Shah U, Talaviya T, Gajjar A. Development and validation of derivative spectroscopic Method for the simultaneous estimation of mebendazole and levamisole hydrochloride in pharmaceutical formulations. Int J Pharm Chem Anal.2015; 2(2):10812.

6. Attia KA, Nassar MW, El-Dosoky M, Madkour AW. Spectrophotometric methods for determination of mebendazole in presence of its alkaline induced degradation product in pure form and pharmaceutical preparation. Ijppr. Human. 2015; 4(3):1-9.

7. Parakh DR, Patil MP, Sonawane SS, Jain CP. Development and validation of Spectrophotometric method for estimation of mebendazole in bulk and pharmaceutical formulation. World J Pharm Res.2015 May 15; 4:2223-35.

8. De Ruyck H, Daeseleire E, De Ridder H. Development and validation of a liquid chromatography-electrospray tandem mass spectrometry method for mebendazole and its metabolites hydroxymebendazole and aminomebendazole in sheep liver. Analyst. 2001; 126(12):2144-8.

9. YU hj, Feng B, Jiang CJ, Zhang XL, Hui YH, Shen XS. Determination of residues of mebendazole and its metabolites in fish/shrimp by solid phase extractionhigh performance liquid chromatography. Chin. J. Anal. Lab. 2010; 4.

10. Calvo NL, Kaufman TS, Maggio RM. Mebendazole crystal forms in tablet formulations. An ATRFTIR/chemometrics approach to polymorph assignment. J Pharm Biomed Anal. 2016 Apr $15 ; 122: 157-65$.

11. Parakh DR, Madagul JK, Mene HR, Patil MP, Kshirsagar SJ. RP-HPLC method development and validation for Quantification of Mebendazole in API and Pharmaceutical Formulations. Pharma Tutor. 2016 May 1; 4(5):46-51.

12. Sangamithirai D, Munusamy S, Narayanan V, Stephen A. Tunable poly (o-anisidine)/carbon nanotubes nanocomposites as an electrochemical sensor for the detection of an anthelmintic drug mebendazole. Polym Bull. 2018 Jul 1; 75(7):3127-47. 
13. Lian Z, Liang Z, Wang J. Selective extraction and concentration of mebendazole in seawater samples using molecularly imprinted polymer as sorbent. Mar Pollut Bull. 2015 Feb 15; 91(1):96-101.

14. de Macedo IY, Garcia LF, de Souza AR, da Silva AM, Fernandez C, Santos MD, et al. Differential pulse voltammetric determination of albendazole and mebendazole in pharmaceutical formulations based on modified sonogel carbon paste electrodes with perovskite-type LaFeO3 nanoparticles. J Electrochem Soc. 2016 Jan 1; 163(8):B428-34.

15. Bharate SS, Bharate SB, Bajaj AN. Interactions and incompatibilities of pharmaceutical excipients with active pharmaceutical ingredients: a comprehensive review. Excip. Food Chem. 2016 Nov 23; 1(3):1131.

\section{التحليل المايكروي لتفاعل الاكسدة لبقايا المبيندازول مع بارا-بروموانلين بوجود ن-بروموسكسينامايد}

سمية محمد عباس 2
تكليف ذياب صلال

1 و وزارة التربية، بغداد، العراق.

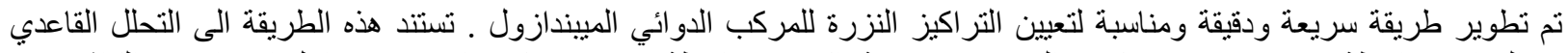

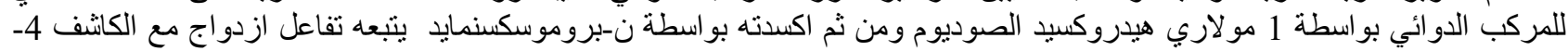

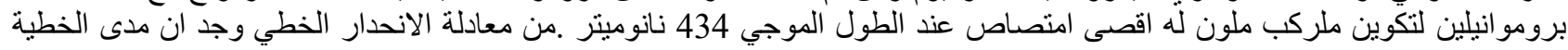

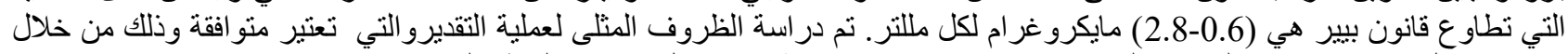

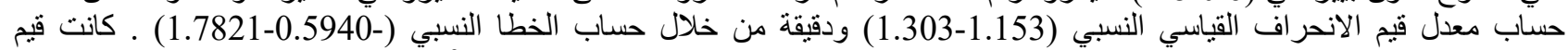

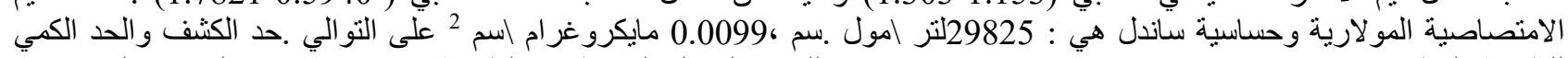

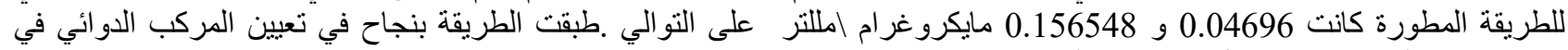
مستحضر اته الصيدلانية وبمعدل استردادية بلغت

الكلمات المفتاحية: ميبيندازول، ن-بروموسكسينامايد، ازدو اج الاكسدة، المطيافية. 